\title{
Minireview
}

\section{Engineering vacancies for solar photocatalytic applications}

\author{
Mingce Long a,b,*, Longhui Zheng a \\ a School of Environmental Science and Engineering, Shanghai Jiao Tong University, Shanghai 200240, China \\ b Key Laboratory for Thin Film and Microfabrication of the Ministry of Education, Shanghai Jiao Tong University, Shanghai 200240, China
}

\section{A R T I C L E I N F}

\section{Article history:}

Accepted 18 November 2016

Published 5 April 2017

Hydrogenated treatment

Photocatalysis

Chemisorption

Titanium vacancy
Received 29 October 2016

\section{Keywords:}

Oxygen vacancy

\begin{abstract}
A B S T R A C T
In contrast to the exploration of novel photocatalytic materials, vacancy engineering of traditional photocatalysts comprising earth-abundant elements represents an effective method for enhancing photocatalytic performance without introducing alien elements. This minireview analyzes the latest progress in engineering vacancies in photocatalysts, remarks on state-of-the-art characterization techniques for vacancies, and reviews the formation chemistry and fundamental benefits of anion and cation vacancies in typical photocatalysts. Although knowledge of these vacancies is increasing, challenges remain in this field, and possible further research is therefore also discussed.
\end{abstract}

(C) 2017, Dalian Institute of Chemical Physics, Chinese Academy of Sciences. Published by Elsevier B.V. All rights reserved.

\section{Introduction}

tions.

Vacancies, or point defects, are prevalent in all semiconductor materials because the conductivity of these materials originates from their inherently nonstoichiometric compositions. All chemical functions of materials, such as catalysis, adsorption or sensing behaviors, are dominated by their electronic structures and surface properties. The vacancies in a material play a critical role in the manipulation of the electronic structure, surface acidic and basic properties, dissociative adsorption, charge transportation, reactivity and other chemical properties of the material, and this has been known for a long time through both theoretical calculations and experimental observations [6-9]. However, the earliest study that directly discussed the influence of vacancies on photocatalytic performance was carried out about two decades ago by Yanagida et al. [10,11]. In their reports, sulfur vacancies on the surface of $\mathrm{CdS}$ were shown to promote the photocatalytic reduction of $\mathrm{CO}_{2}$ and the selective production of CO $[10,11]$. Studies on oxygen vacancies $\left(V_{0}\right)$ in

\footnotetext{
* Corresponding author. Tel: +86-21-54747354; Fax: +86-21-54740825; E-mail: long_mc@sjtu.edu.cn

This work was supported by the National Natural Science Foundation of China (21377084) and Special Fund for Agro-scientific Research in the Public Interest (201503107).

DOI: 10.1016/S1872-2067(17)62821-3 | http://www.sciencedirect.com/science/journal/18722067 | Chin. J. Catal., Vol. 38, No. 4, April 2017
} 
photocatalysis increased dramatically in the 2000s and, accompanied by the development of visible light-driven $\mathrm{TiO}_{2}$ catalysts [12], accelerated further after promising results were obtained from black $\mathrm{TiO}_{2}$ and subsequent research [13-15]. Recently, vacancy-rich photocatalysts containing other vacancies besides $V_{0}$ have been developed. These vacancies include anion vacancies such as sulfur [16], halogen [17-19], and nitrogen vacancies [20-23]; cation vacancies such as bismuth $[24,25]$, titanium [26,27], and carbon vacancies [28,29]; and combinations of both anion and cation vacancies $[24,30]$.

Vacancy engineering provides a number of notable advantages for high performance photocatalysts: (1) an approach to manipulating the compositions of catalysts without the introduction of impurities; (2) simultaneous tuning of the concentrations and types of vacancies in the bulk or surface lattice to meet requirements closely related to photocatalytic performance (e.g., narrow band gaps, enhanced optical absorption and improved charge separation); (3) a promising low-cost method using simple synthetic techniques to modify traditional photocatalysts composed of earth abundant elements, in contrast to modification using complicated procedures and rare elements; (4) a possible method to simultaneously influence thermocatalysis and photocatalysis by enabling surface chemisorption.

The critical functions of $V_{0}$ on the photocatalytic performance of $\mathrm{TiO}_{2}$ have been frequently reviewed [31-34]. In this minireview, we will introduce and discuss the latest progress regarding a broader range of anion and cation vacancies, and focus on their characterization, formation chemistry and fundamental benefits for photocatalysis.

\section{Vacancy characterization}

It is essential to characterize the existence, concentration and type of vacancies present in a material. The existence of vacancies can be confirmed by measuring the stoichiometric ratios of elements using elemental analysis, X-ray fluorescence (XRF), X-ray photoelectron spectroscopy (XPS) or Rietveld refinement methods. Vacancies can also be directly observed by scanning tunneling microscopy (STM) [8], or indirectly characterized by cataluminescence [35], photoluminescence [36], electron spin resonance (ESR) [12], or other techniques. ESR is a typical measurement used to confirm the existence of $V_{0}$, which exhibits a signal at $g=2.004$. A signal at $g=1.998$ was observed in p-type $\mathrm{TiO}_{2}$ and attributed to titanium vacancies $\left(\mathrm{V}_{\mathrm{Ti}}\right)$ [26]. However, these methods cannot distinguish among the different types of vacancies or determine their concentrations.

Positron annihilation spectroscopy is a powerful technique for investigating defects in materials, and can provide information on vacancy types and their relative concentrations $[24,37,38]$. Three positron lifetimes $\left(\tau_{1}, \tau_{2}\right.$ and $\left.\tau_{3}\right)$ and their relative intensities were obtained from the positron lifetime spectra of $\mathrm{TiO}_{2}$ and $\mathrm{CeO}_{2}$ nanoparticles. The positron lifetimes, from shortest to longest, were attributed to small $V_{0}$ in the bulk, larger clusters of $\mathrm{V}_{0}$ on the surface, and large voids in the material, respectively. The relative concentration of bulk de- fects to surface defects can be estimated from the ratio of the intensities of the two corresponding peaks ( $\tau_{1}$ and $\tau_{2}$ ). It was thus shown that a lower relative concentration of bulk vacancies in a $\mathrm{TiO}_{2}$ crystal corresponds to a higher photocatalytic performance because of improved charge separation [37]. In contrast, there is a positive relationship between the presence of large $\mathrm{V}_{0}$ clusters on the surface of $\mathrm{CeO}_{2}$ and the reducibility and reactivity of the photocatalyst [38]. Moreover, four positron lifetime components were observed in the spectra of ultrathin BiOCl nanosheets and nanoplates [24]. The shortest of these ( $\sim 250 \mathrm{ps})$ was attributed to single isolated bismuth vacancies $\left(\mathrm{V}_{\mathrm{Bi}}\right)$, and the second shortest $(\sim 325 \mathrm{ps})$ to $\mathrm{Bi}^{3+}-$ oxygen vacancy associates. According to their relative intensities, the associated vacancies were dominant in ultrathin $\mathrm{BiOCl}$ nanosheets [24]. However, despite the success of positron annihilation in defect characterization, further knowledge of the various vacancies is required, and more advanced techniques are also desirable for a better understanding of the fundamental relationships between vacancies in the lattices of photocatalysts and their photocatalytic properties.

\section{Anion vacancies}

The anion vacancies in photocatalytic materials are most often oxygen, nitrogen, sulfur, and halogen vacancies. Owing to the instability of sulfide photocatalysts, there are very few reports on photocatalysts containing sulfur vacancies [16]. In contrast, $\mathrm{V}_{0}$ in metal oxides have frequently been investigated because most photocatalysts are n-type metal oxide nanoparticles, in which the conductivity originates from Vo. Fig. 1 shows the oxygen and titanium vacancies in a defect-containing $\mathrm{TiO}_{2}$ lattice without dopants.

Although $V_{0}$ occur naturally in materials, higher density $V_{0}$ can be generated by aliovalent ion doping (e.g., nitrogen doping) [39], formation of two-dimensional ultrathin materials [24], solid-state chemical reduction by $\mathrm{NaBH}_{4}$ [40-42], plasma treatment [12], addition of chelation precursors with carboxylic acids [43], hydrothermal reduction with graphene oxide [44], or annealing in an inert or reducing gas atmosphere (e.g.,

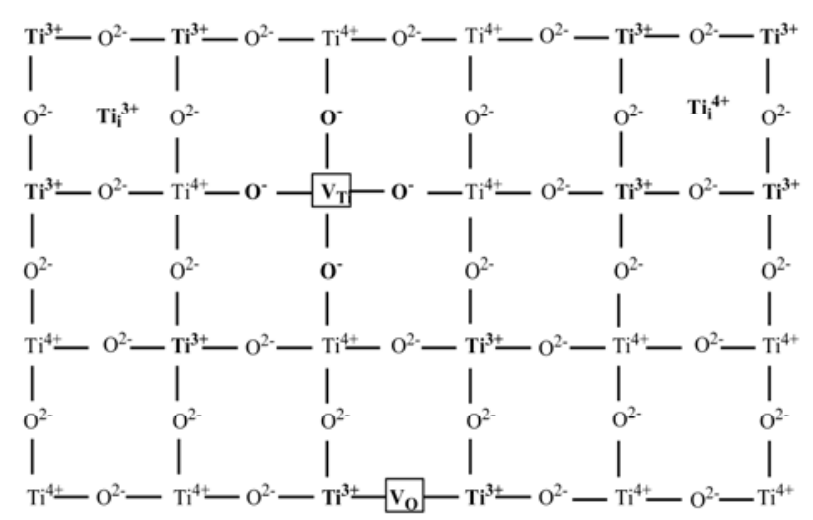

Fig. 1. Schematic representation of a defect-containing $\mathrm{TiO}_{2}$ lattice without dopants: $\mathrm{V}_{\mathrm{O}} / \mathrm{V}_{\mathrm{Ti}}$, oxygen/titanium vacancy; $\mathrm{Ti}^{3+}, \mathrm{Ti}^{3+}$ ion in a titanium lattice site (quasi-free electron); $\mathrm{O}^{-}, \mathrm{O}^{-}$ion in an oxygen lattice site (quasi-free hole); $\mathrm{Ti}_{i}^{3+} / \mathrm{Ti}^{4+}, \mathrm{Ti}^{3+} / \mathrm{Ti}^{4+}$ ion in an interstitial site (modified from Ref. [31]). 
hydrogen) [13,45]. Solid-state chemical reduction with $\mathrm{NaBH}_{4}$ is a facile method, and the resulting colored products feature an amorphous shell with $V_{0}$ [40]. However, hydrogen treatment (HT) has also attracted considerable attention after the pioneering work by Mao's group [13]. In fact, HT has been used historically to tailor the optical and electric properties of single crystal oxide materials [46]. This method was applied to $\mathrm{TiO}_{2}$ nanoparticles and found to be effective in improving their photooxidation performance in as early as 2003 [47]. However, it is only since the exciting results with black $\mathrm{TiO}_{2}$ that $\mathrm{HT}$ has become an important area of research and been explored extensively for the treatment of $\mathrm{TiO}_{2}, \alpha-\mathrm{Fe}_{2} \mathrm{O}_{3}, \mathrm{WO}_{3}, \mathrm{BiVO}_{4}$, and other photocatalysts with various nanoarchitectures [48-51]. After HT, both high density $V_{0}$ and the resulting defect disorders are generated on the surface layer of the nanomaterials. Some results have indicated that the change in the properties of the materials was mainly caused by the high density of surface $V_{0}$ trap sites [36]. However, others have suggested that both $V_{0}$ and the surface structural disorder play a synergistic role, in which $V_{0}$ mainly exists in the bulk of the lattice, but the surface structural disorder is almost stoichiometric [52].

The improved photocatalytic performance after HT has been ascribed to two main effects. First, after HT, the optical absorption of the photocatalysts was greatly extended to the near infrared (NIR) range $(\sim 1200 \mathrm{~nm})$. The visible light absorption was attributed to the localized mid-bandgap $\mathrm{V}_{0}$ occupied by an unpaired electron in an antibonding orbital at a surface site [36]. These $V_{0}$ states are located at $0.7-1.0 \mathrm{eV}$ below the conduction band (CB) (Fig. 2(A) [12,46,52]). Therefore, the electrons can be excited from the valence band (VB) and localized $V_{O}$ states to the CB or from the VB to localized $V_{0}$ states by lower energy photons, and this results in a considerably broadened absorption. Second, a high $V_{0}$ density causes an increase in the donor density in the photocatalysts because the $\mathrm{V}_{0}$ function as electron donors. After HT, the donor density in
$\mathrm{TiO}_{2}$ nanowires was three orders of magnitudes higher than the density before HT [14]. This increased donor density not only improves the charge transport in the lattice, but also promotes electron transfer at the interface because the upward shift of the Fermi level toward the $\mathrm{CB}$ as a result of the increased donor density augments the band bending. However, the considerable improvement in the photoactivity was mainly ascribed to the enhanced performance in the UV region, but not in the visible light region $[14,15]$. This was confirmed by time-resolved fluorescence (TRF) and femtosecond transient absorption (TA) spectroscopy, which indicated that the charge carriers slowly decayed on UV excitation, but showed considerable recombination on visible light irradiation [34]. It remains a challenge to effectively utilize the absorption in the vis-NIR range, despite the fact that the integration of photo- and thermocatalysis has great potential for maximizing the use of low energy photons [15,51,53-55]. Besides the two benefits mentioned above, HT has also been found to improve the photostability of $\mathrm{WO}_{3}$ by $\mathrm{V}_{0}$ production and formation of substoichiometric $\mathrm{WO}_{3-x}$, which was highly resistant to reoxidation and dissolution induced by peroxo species [49].

More importantly, vacancies function as active sites and enhance the adsorption of reactants (e.g., oxygen, water, or organic molecules), promote electron migration from materials to adsorbates, and can even directly participate in specific photocatalytic or photochemical reactions. One fundamental feature of Vo-rich oxides is their ability to chemisorb oxygen species, which also contributes to the stabilization of $\mathrm{V}_{0}$. Engineering of nondopant $\mathrm{V}_{\mathrm{O}}$ in $\mathrm{CeO}_{2}$ is an important method for promoting the catalytic oxidation of $\mathrm{CO}$ by providing coordinatively unsaturated sites [56]. Interestingly, the inverse reaction, selective photochemical conversion of $\mathrm{CO}_{2}$ to $\mathrm{CO}$, was also found to be mediated by $\mathrm{V}_{0}$, which facilitated electron migration from $\mathrm{CeO}_{2}$ to the chemically adsorbed and preactivated $\mathrm{CO}_{2}$ molecules. Simultaneously, owing to the consumption of $\mathrm{V}_{0}$
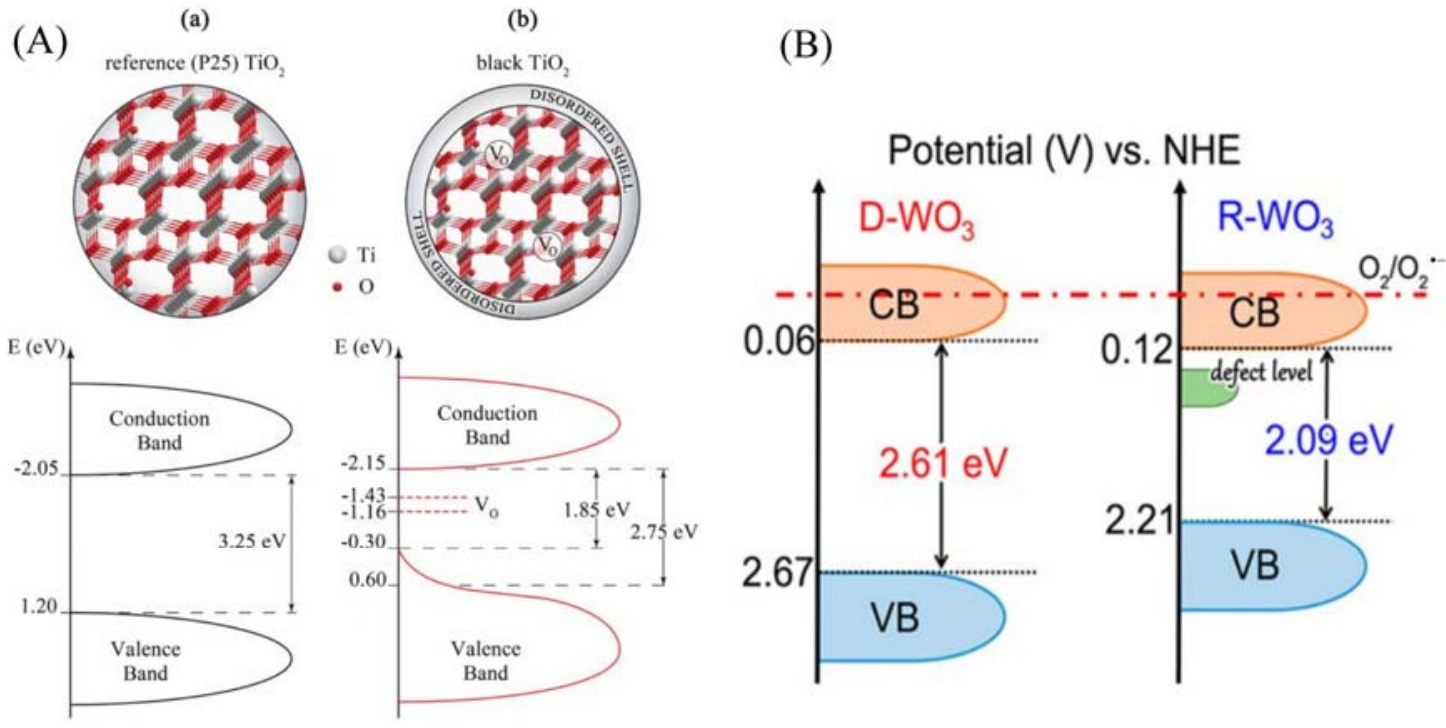

Fig. 2. (A) Schematic of the nanoparticle structure and band structure models for (a) $\mathrm{TiO}_{2}$ and (b) black TiO 2 [52]; (B) Band structure models for defect-deficient $\mathrm{WO}_{3}\left(\mathrm{D}-\mathrm{WO}_{3}\right)$ and defect rich $\mathrm{WO}_{3}\left(\mathrm{R}-\mathrm{WO}_{3}\right)$ [45]. 
in the reaction, $\mathrm{CO}_{2}$ photoreduction slowed down and was eventually terminated [57].

Based on their behavior in both photo- and thermocatalysis, vacancies could bridge them and enable a synergistic effect for the utilization of solar energy, even in the vis-NIR range. $V_{0}$ were observed as electron-transfer mediators in the thermocatalytic decomposition of $\mathrm{CO}_{2}$ on mesoporous $\mathrm{WO}_{3}$, in which $\mathrm{V}_{\mathrm{O}}$ were consumed to produce $\mathrm{C} / \mathrm{CO}$ [51]. A synergistic photo/thermocatalytic process with a high selectivity for the conversion of $\mathrm{CO}_{2}$ into $\mathrm{CH}_{4}$ was accordingly developed using this $\mathrm{V}_{0}$-rich $\mathrm{WO}_{3}$ [51], which represents an important strategy for the combination of photo- and thermocatalysis to realize $\mathrm{CO}_{2}$ reduction. However, it would be more desirable to achieve combined photo/thermocatalysis using only solar energy, thus avoiding external energy inputs. Recently, highly selective aerobic coupling of amines to the corresponding imines was achieved under NIR illumination $\left(>700 \mathrm{~nm}\right.$ ) on $\mathrm{V}_{0}$-rich $\mathrm{WO}_{3}$ nanosheets (Fig. 2(B) [45]. The low energy photons were used to generate superoxide radicals $\left(\mathrm{O}_{2}{ }^{--}\right)$in a chemisorbed state at $\mathrm{V}_{0}$ sites. This was achieved by electron transfer from $\mathrm{V}_{0}$ to the chemisorbed oxygen as a result of the strong electronic coupling between them. Band excitation at the reduction level for free $\mathrm{O}_{2} / \mathrm{O}_{2}{ }^{--}(-0.33 \mathrm{~V}$ vs. NHE) is not required in this process. Surprising stability was obtained owing to the recovery of surface $\mathrm{V}_{\mathrm{O}}$ in the reaction between $\mathrm{O}_{2}{ }^{--}$and neighboring activated benzylamine. The utilization of low energy photons is thus a promising strategy for the selective conversion of substrates using $\mathrm{V}_{0}$.

The presence of nitrogen vacancies $\left(\mathrm{V}_{\mathrm{N}}\right)$ is an intrinsic property of nonstoichiometric nitride photocatalysts, such as $\mathrm{Ta}_{3} \mathrm{~N}_{5}[58,59]$ and metal-free $\mathrm{g}-\mathrm{C}_{3} \mathrm{~N}_{4}[20,22] . \mathrm{V}_{\mathrm{N}}$-containing g- $\mathrm{C}_{3} \mathrm{~N}_{4}$ was first produced by controlling the polycondensation temperature of dicyandiamide in an open container, and promoted the photodecomposition of RhB [22]. In this material, the number of short- and long-lived charge carriers was decreased and increased, respectively. This suppressed charge-carrier recombination was attributed to the trapping of charge carriers in the localized electronic states of $\mathrm{V}_{\mathrm{N}}$, and the accordingly reduced spatial overlap. Thermal treatment in a hydrogen or nitrogen atmosphere, sulfur doping, and microwave synthesis have also been reported to produce g- $\mathrm{C}_{3} \mathrm{~N}_{4}$ with $V_{N}[20,21,23,60-62]$. Compared with traditional modification of only the surface layer of photocatalysts, homogeneous modification features a complete change in the electronic structure of the photocatalyst, and can be realized by using layered nanostructured precursors [63]. Hydrogenation of the layered structural melon was used for the homogeneous self-modification of $\mathrm{g}-\mathrm{C}_{3} \mathrm{~N}_{4}$ with $\mathrm{V}_{\mathrm{N}}$, and this material had a greatly reduced band gap (2.03 eV) [20]. However, a reduced redox ability was expected owing to the band shifts in this modified g- $\mathrm{C}_{3} \mathrm{~N}_{4}$. In addition to its enhanced performance in photocatalytic oxidation and water splitting, $\mathrm{V}_{\mathrm{N}}$-containing g- $\mathrm{C}_{3} \mathrm{~N}_{4}$ also shows great potential in nitrogen fixation $[23,61,62]$. As well as promoting interfacial charge transfer from the catalyst to the adsorbed $\mathrm{N}_{2}$, the $\mathrm{V}_{\mathrm{N}}$ in g- $\mathrm{C}_{3} \mathrm{~N}_{4}$ can also serve as selective chemical adsorption sites for the adsorption, activation and reduction of $\mathrm{N}_{2}$ because of their similar proper- ties to those of $\mathrm{N}_{2}$-imprinted polymers [23]. The use of $\mathrm{V}_{\mathrm{N}}$-containing nitride photocatalysts with a negative conduction band may also be a promising strategy for the reduction of nitrogen-containing compounds.

Halogen vacancies $\left(\mathrm{V}_{\mathrm{H}}\right)$ are easily generated in bismuth oxyhalides, which have unique layered structures consisting of positively charged $\left[\mathrm{Bi}_{2} \mathrm{O}_{2}\right]^{2+}$ slabs and interleaved negative halogen slabs with nonbonding interactions along the $c$-axis $[17,19]$. Because of the weak van der Waals interactions, halogen ions can diffuse out of the layered structure by calcination, or be replaced by other halogen ions through ion exchange in the solution or solid state. Generally, bismuth oxyhalides possess diverse halogen-deficient crystal phases, which can be obtained simply by tuning the precursor ratios or/and calcining at relatively high temperatures. However, we recently observed that $\mathrm{Bi}_{7} \mathrm{O}_{9} \mathrm{I}_{3}$ containing iodine vacancies could be obtained by calcination below the phase transition temperature $[17,18]$. The iodine deficiency was indicated by the decrease in the $\mathrm{Bi} / \mathrm{I}$ atomic ratio from 2.36 to 2.80 after calcination at 350 ${ }^{\circ} \mathrm{C}$. It was found that shallow $\mathrm{V}_{\mathrm{H}}$ improve the carrier transport properties, whereas deep $V_{H}$ have the opposite effect [64]. Homogeneous modification of the bismuth oxyiodides with iodine vacancies is expected because of their layered structure, and the whole band gap increased from 2.04 to $2.31 \mathrm{eV}$ after calcination at $350{ }^{\circ} \mathrm{C}$. Moreover, the enlargement of the band gap was confirmed by theoretical calculations, which also indicated the downward shift of the band position and the transition of the semiconductor behavior from $\mathrm{p}$ to $\mathrm{n}$ type. These changes are expected to increase the oxidation ability of the photogenerated holes, improve the electron mobility, and accordingly contribute to an enhanced photooxidation performance. However, although $\mathrm{V}_{\mathrm{H}}$ can easily be created in layered structural bismuth oxyhalides, there are concerns about the stability of these compounds, especially in the aqueous phase, which greatly restricts their application in water purification.

\section{Cation vacancies}

There are very few reports on cation vacancies in the field of photocatalysis. In contrast to anion vacancies and cation interstitials, which are shallow donors, cation vacancies are shallow acceptors and always induce p-type conductivity. The benefits of $\mathrm{V}_{\mathrm{Ti}}$ in $\mathrm{TiO}_{2}$ are expected to include: (1) increase in the electrical conductivity of the ionic components; (2) increase in the mobility of electrons and interfacial transfer of charge carriers, which suppresses recombination and enhances the photocatalytic activity; (3) generation of room-temperature ferromagnetism; and (4) provision of surface active sites for water adsorption and formation of active complexes, and the corresponding enhanced photoactivity in water splitting [65-67]. Some experimental results have indicated that the band gap of $\mathrm{TiO}_{2}$ is independent of the $\mathrm{V}_{\mathrm{Ti}}$ concentration $[26,65]$. Theoretical calculations have also suggested that $\mathrm{V}_{\mathrm{Ti}}$ would not generate new states in the band gap. However, the presence of $\mathrm{V}_{\mathrm{Ti}}$ in $\mathrm{TiO}_{2}$ nanosheets caused a slight downward shift in the VB maximum and a considerable downward shift in the CB minimum; thus resulting in a net narrowed band gap [67]. 
It is difficult to generate stable cation vacancies in traditional n-type oxides, for example, $\mathrm{V}_{\mathrm{Ti}}$ in $\mathrm{TiO}_{2}$. Nowotny et al. [68] found that the transport kinetics of $\mathrm{V}_{\mathrm{Ti}}$ in $\mathrm{TiO}_{2}$ were much slower than those of $\mathrm{V}_{\mathrm{O}}$ and titanium interstitials, and accordingly resulted in quasi-quenches of the $\mathrm{V}_{\mathrm{Ti}}$ species. Therefore, $\mathrm{V}_{\mathrm{Ti}}$ are expected to be restricted to the surface or near-surface regions, which could be one of the reasons for the difficulty in synthesizing $\mathrm{V}_{\mathrm{Ti}}$-containing $\mathrm{TiO}_{2}$. However, p-type $\mathrm{TiO}_{2}$ containing $\mathrm{V}_{\mathrm{Ti}}$ can be engineered in the following ways: (1) generation of defect disorder by calcination above $1573 \mathrm{~K}$ [69]; (2) prolonged oxidation $\left(p\left(\mathrm{O}_{2}\right)=75 \mathrm{kPa}\right)$ at temperatures above $1273 \mathrm{~K}[27,65,70]$; (3) incorporation of aliovalent dopant ions $[71,72]$; and (4) controlled calcination of lamellated titanium glycerolate [26]. According to Rietveld refinement results, high concentrations of titanium defects were present in iron-doped $\mathrm{TiO}_{2}$ [71] or $\mathrm{TiO}_{2}$ with a particle size of several nanometers [73]. Moreover, the concentration of $\mathrm{V}_{\mathrm{Ti}}$ increased with increasing iron content and decreased with increasing particle size, but remained stable when the vacancies were balanced by hydroxyl ions or protons in the lattice. Recently, Zou's group $[26,74]$ developed stable p-type $\mathrm{ZnO}$ and $\mathrm{TiO}_{2}$ with cation vacancies by calcination of the glycerolate precursors. These p-type oxides are formed through the generation of oxygen-rich structures during the decomposition of interlayer organic groups at high temperatures, which creates distortion and thus generates cation vacancies in the lattice. This method represents a promising way of producing photocatalysts with cation vacancies. However, although the generation of $\mathrm{V}_{\mathrm{Ti}}$ has been greatly improved and the benefits have been theoretically discussed, the characterization of these vacancies, and their stability and effects in photocatalytic interfacial processes are far from clear.

In contrast to $\mathrm{V}_{\mathrm{N}}$-containing g- $\mathrm{C}_{3} \mathrm{~N}_{4}$, g- $\mathrm{C}_{3} \mathrm{~N}_{4}$ containing cation carbon vacancies $\left(\mathrm{V}_{\mathrm{C}}\right)$ can be developed by thermally treating bulk g- $\mathrm{C}_{3} \mathrm{~N}_{4}$ in an $\mathrm{NH}_{3}$ or $\mathrm{Ar}$ atmosphere $[28,29]$. In addition, $\mathrm{V}_{\mathrm{C}}$-induced room-temperature ferromagnetism of $\mathrm{g}-\mathrm{C}_{3} \mathrm{~N}_{4}$ has been confirmed [29]. The dramatically improved photocatalytic hydrogen evolution was attributed to the higher donor density and the notably longer lifetime of the charge carriers. Moreover, $\mathrm{V}_{\mathrm{C}}$-containing g- $\mathrm{C}_{3} \mathrm{~N}_{4}$ displayed considerably higher $\mathrm{H}_{2} \mathrm{O}_{2}$ production than both pure g- $\mathrm{C}_{3} \mathrm{~N}_{4}$ and $\mathrm{V}_{\mathrm{N}}$-containing g- $\mathrm{C}_{3} \mathrm{~N}_{4}$ [28]. This was not only attributed to the enhanced optical absorption and higher donor density of $\mathrm{V}_{\mathrm{C}}$-containing g- $\mathrm{C}_{3} \mathrm{~N}_{4}$, but also to its improved $\mathrm{O}_{2}$ adsorption, the promotion of electron transfer for $\mathrm{O}_{2}$ reduction, and most importantly, the transformation of $\mathrm{O}_{2}$ reduction into a two-electron process, in which the amino groups around the $\mathrm{V}_{\mathrm{C}}$ had an indispensable role. This suggests that cation vacancies in $\mathrm{g}-\mathrm{C}_{3} \mathrm{~N}_{4}$ have great potential for certain photocatalytic applications.

Bismuth oxide-based photocatalysts have attracted considerable attention, owing to their narrow band gap and high activity in the visible light range, as well as the relative abundance of elemental bismuth $[18,75]$. Bismuth vacancies $\left(\mathrm{V}_{\mathrm{Bi}}\right)$ are also ubiquitous in nonstoichiometric bismuth-oxide compounds $[24,25,76,77]$. Various bulk defects, including $V_{0}$ and $V_{B i}$, were observed in ball-milled $\mathrm{BiPO}_{4}$ [76]. These defects degraded the photocatalytic performance of $\mathrm{BiPO}_{4}$, but were easily removed by reflux or calcination. Recently, a stable $\mathrm{V}_{\mathrm{Bi}}$-containing $\mathrm{Bi}_{6} \mathrm{~S}_{2} \mathrm{O}_{15}$ was developed by increasing the ratio of the sulfate to bismuth sources in the hydrothermal synthesis [25]. The resulting catalyst was characterized as core-shell nanowires with a disordered shell layer containing a high concentration of $\mathrm{V}_{\mathrm{Bi}}$. These vacancies contributed to the efficient separation of charge carriers, and reduced the size of the band gap by elevating the whole band and producing shallow surface states above the VB.

The components and concentration of vacancies in the surface lattice are facet-dependent; therefore, two-dimensional materials with different facets and thicknesses have different vacancy compositions. In general, $\mathrm{V}_{\mathrm{Bi}}$ dominate on the surface of BiOCl nanoplates. However, when the thickness of the nanoplates was reduced to $2.7 \mathrm{~nm}, \mathrm{Bi}^{3+}$-oxygen vacancy associates were observed to dominate on the surface of these ultrathin BiOCl nanosheets. This resulted in a strongly negatively charged surface and a smaller band gap, and the separation of photogenerated charges was promoted [24]. Specific facets of ultrathin photocatalytic materials are exposed on light irradiation or chemical reaction; this could provide a delicate strategy for tuning the available vacancies for photocatalytic applications.

\section{Conclusion and prospect}

The latest progress in this field provides a greater fundamental understanding of the relationship between a diverse range of vacancies and their related photocatalytic properties, and the growing knowledge has been successfully applied to realize advanced photocatalytic processes for water splitting, $\mathrm{N}_{2}$ fixation, $\mathrm{H}_{2} \mathrm{O}_{2}$ production, decontamination, organic synthesis, and $\mathrm{CO}_{2}$ reduction, among others. Vacancy-rich photocatalysts display extended optical absorption, facilitate charge separation and enhance the selective chemisorption of reactants, which all result in improved photoreactivity. However, further efforts are required to deal with the following open problems or challenges. (1) More powerful characterization techniques are needed to reveal the existence, format and concentration of the vacancies. This is essential for the understanding the association between vacancies and photocatalytic performance. Currently, we cannot easily discern the different types of vacancies, let alone the format of the vacancies in the lattice surface, subsurface or bulk. (2) Current knowledge on the formation chemistry and fundamental functions of anion or cation vacancies in photocatalytic processes is insufficient and far from clear, especially for those photocatalysts containing both donor and acceptor vacancies [24,30]. (3) It is desirable that vacancies in photocatalysts retain their function and remain unchanged for long periods of time. However, although we can obtain stable vacancy-rich compounds, and we understand the dependence of stability on the vacancy format according to theoretical calculations [78], we do not yet know the exact factors that control the stability of vacancies, or how to manipulate the raw materials and synthetic methods to tune the format of the vacancies. It is expected that increasing attention on vacancies in photocatalysts and the development of vacan- 
cy-engineering techniques will mean that their use in solar photocatalytic applications will be greatly accelerated in the near future.

\section{References}

[1] G. Liu, J. C. Yu, G. Q. Lu, H. M. Cheng, Chem. Commun., 2011, 47, 6763-6783.

[2] A. Kubacka, M. Fernandez-Garcia, G. Colon, Chem. Rev., 2012, 112, $1555-1614$.

[3] H. J. Li, Y. Zhou, W. G. Tu, J. H. Ye, Z. G. Zou, Adv. Funct. Mater., 2015, 25, 998-1013.

[4] X. P. Chen, Z. X. Zhang, L. N. Chi, A. K. Nair, W. F. Shangguan, Z. Jiang, Nano-Micro. Lett., 2016, 8, 1-12.

[5] A. Kudo, H. Kato, I. Tsuji, Chem. Lett., 2004, 33, 1534-1539.

[6] U. Diebold, Surf. Sci. Rep., 2003, 48, 53-229.

[7] G. S. Li, L. P. Li, J. Zheng, Sci. China Chem., 2011, 54, 876-886.

[8] F. Esch, S. Fabris, L. Zhou, T. Montini, C. Africh, P. Fornasiero, G. Comelli, R. Rosei, Science, 2005, 309, 752-755.

[9] Y. Kang, Q. Leng, D. L. Guo, D. Z. Yang, Y. P. Pu, C. G. Hu. Nano-Micro Lett., 2015, 7, 2150.

[10] H. Fujiwara, H. Hosokawa, K. Murakoshi, Y. Wada, S. Yanagida, T. Okada, H. Kobayashi, J. Phys. Chem. B, 1997, 101, 8270-8278.

[11] H. Fujiwara, H. Hosokawa, K. Murakoshi, Y. Wada, S. Yanagida, Langmuir, 1998, 14, 5154-5159.

[12] I. Nakamura, N. Negishi, S. Kutsuna, T. Ihara, S. Sugihara, E. Takeuchi, J. Mol. Catal. A, 2000, 161, 205-212.

[13] X. B. Chen, L. Liu, P. Y. Yu, S. S. Mao, Science, 2011, 331, 746-750.

[14] G. M. Wang, H. Y. Wang, Y. C. Ling, Y. C. Tang, X. Y. Yang, R. C. Fitzmorris, C. C. Wang, J. Z. Zhang, Y. Li, Nano Lett., 2011, 11, 3026-3033.

[15] Y. H. Hu, Angew. Chem. Int. Ed., 2012, 51, 12410-12412.

[16] X. Y. Zhang, Z. Zhao, W. W. Zhang, G. Q. Zhang, D. Qu, X. Miao, S. R. Sun, Z. C. Sun, Small, 2016, 12, 793-801.

[17] M. C. Long, P. D. Hu, H. D. Wu, Y. Y. Chen, B. H. Tan, W. M. Cai, J. Mater. Chem. A, 2015, 3,5592-5598.

[18] M. C. Long, P. D. Hu, H. D. Wu, J. Cai, B. H. Tan, B. X. Zhou, Appl. Catal. B, 2016, 184, 20-27.

[19] J. Li, Y. Yu, L. Zhang, Nanoscale, 2014, 6, 8473-8488.

[20] P. Niu, L. C. Yin, Y. Q. Yang, G. Liu, H. M. Cheng, Adv. Mater., 2014, $26,8046-8052$.
[21] X. L. Wang, W. Q. Fang, Y. F. Yao, P. R. Liu, Y. Wang, H. M. Zhang, H. J. Zhao, H. G. Yang, $R S C$ Adv., 2015, 5, 21430-21433.

[22] P. Niu, G. Liu, H. M. Cheng, J. Phys. Chem. C, 2012, 116, 11013-11018.

[23] G. H. Dong, W. K. Ho, C. Y. Wang, J. Mater. Chem. A, 2015, 3, 23435-23441.

[24] M. L. Guan, C. Xiao, J. Zhang, S. J. Fan, R. An, Q. M. Cheng, J. F. Xie, M. Zhou, B. J. Ye, Y. Xie, J. Am. Chem. Soc., 2013, 135, 10411-10417.

[25] J. Wang, W. J. Jiang, D. Liu, Z. Wei, Y. F. Zhu, Appl. Catal. B, 2015, 176, 306-314.

[26] S. B. Wang, L. Pan, J. J. Song, W. B. Mi, J. J. Zou, L. Wang, X. W. Zhang, J. Am. Chem. Soc., 2015, 137, 2975-2983.

[27] M. K. Nowotny, P. Bogdanoff, T. Dittrich, S. Fiechter, A. Fujishima, H. Tributsch, Mater. Lett., 2010, 64, 928-930.

[28] S. N. Li, G. H. Dong, R. Hailili, L. P. Yang, Y. X. Li, F. Wang, Y. B. Zeng, C. Y. Wang, Appl. Catal. B, 2016, 190, 26-35.

[29] Q. H. Liang, Z. Li, Z. H. Huang, F. Y. Kang, Q. H. Yang, Adv. Funct. Mater., 2015, 25, 6885-6892.

[30] Q. P. Wu, F. Huang, M. S. Zhao, J. Xu, J. C. Zhou, Y. S. Wang, Nano Energy, 2016, 24, 63-71.

[31] M. K. Nowotny, L. R. Sheppard, T. Bak, J. Nowotny, J. Phys. Chem. C, 2008, 112, 5275-5300.

[32] X. Y. Pan, M. Q. Yang, X. Z. Fu, N. Zhang, Y. J. Xu, Nanoscale, 2013, 5, 3601-3614.

[33] J. Nowotny, M. Abdu, T. Bak, M. A. Idris, M. Ionescu, K. Prince, M. Z. Sahdan, K. Sopian, M. A. M. Teridi, W. Sigmund, Chem. Soc. Rev., 2015, 44, 8424-8442.

[34] H. N. Cui, H. Liu, J. Y. Shi, C. Wang, Int. J. Photoenergy, 2013, 364802/1-364802/17.

[35] L. J. Zhang, S. Wang, C. Lu, Anal. Chem., 2015, 87, 7313-7320.

[36] D. A. Wheeler, Y. C. Ling, R. J. Dillon, R. C. Fitzmorris, C. G. Dudzik, L. Zavodivker, T. Rajh, N. M. Dimitrijevic, G. Millhauser, C. Bardeen, Y. Li, J. Z. Zhang, J. Phys. Chem. C, 2013, 117, 26821-26830.

[37] M. Kong, Y. Z. Li, X. Chen, T. T. Tian, P. F. Fang, F. Zheng, X. J. Zhao, J. Am. Chem. Soc., 2011, 133, 16414-16417.

[38] X. W. Liu, K. B. Zhou, L. Wang, B. Y. Wang, Y. D. Li, J. Am. Chem. Soc., 2009, 131, 3140-3141.

[39] C. Di Valentin, G. Pacchioni, A. Selloni, S. Livraghi, E. Giamello, J. Phys. Chem. B, 2005, 109, 11414-11419.

[40] H. Q. Tan, Z. Zhao, M. Niu, C. Y. Mao, D. P. Cao, D. J. Cheng, P. Y. Feng, Z. C. Sun, Nanoscale, 2014, 6, 10216-10223.

\section{Graphical Abstract}

Chin. J. Catal., 2017, 38: 617-624 doi: 10.1016/S1872-2067(17)62821-3

\section{Engineering vacancies for solar photocatalytic applications}

Mingce Long *, Longhui Zheng

Shanghai Jiao Tong University

Engineering of vacancies represents an effective strategy to boost photocatalytic processes for solar energy applications. This minireview analyzes the latest progress in the engineering of anion and cation vacancies in the field of photocatalysis.

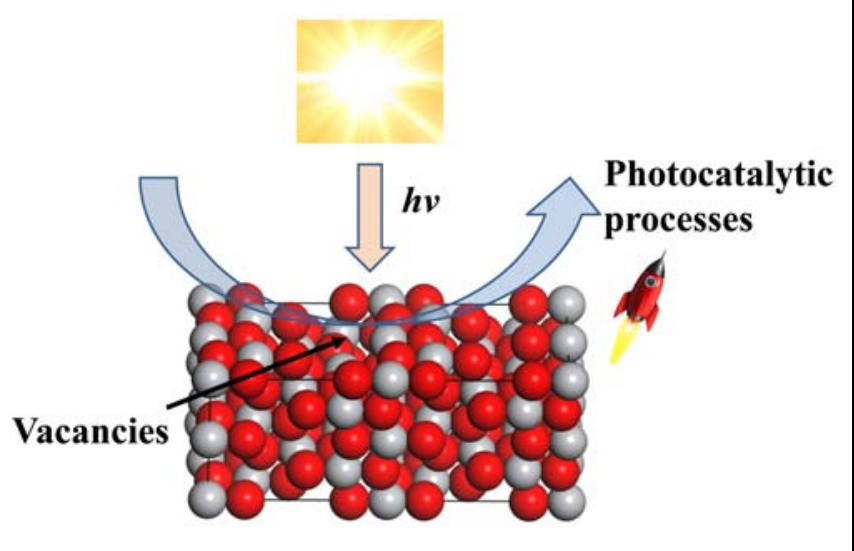


[41] H. Q. Tan, Z. Zhao, W. B. Zhu, E. N. Coker, B. S. Li, M. Zheng, W. X. Yu, H. Y. Fan, Z. C. Sun, ACS Appl. Mater. Interfaces, 2014, 6, 19184-19190.

[42] Z. Zhao, X. Y. Zhang, G. Q. Zhang, Z. Y. Liu, D. Qu, X. Miao, P. Y. Feng, Z. C. Sun, Nano Res., 2015, 8, 4061-4071.

[43] X. J. Wang, Y. Zhao, F. T. Li, L. J. Dou, Y. P. Li, J. Zhao, Y. J. Hao, Sci. Rep., 2016, 6, 24918.

[44] M. C. Long, Y. L. Qin, C. Chen, X. Y. Guo, B. H. Tan, W. M. Cai, J. Phys. Chem. C, 2013, 117, 16734-16741.

[45] N. Zhang, X. Y. Li, H. C. Ye, S. M. Chen, H. X. Ju, D. B. Liu, Y. Lin, W. Ye, C. M. Wang, Q. Xu, J. F. Zhu, L. Song, J. Jiang, Y. J. Xiong, J. Am. Chem. Soc., 2016, 138, 8928-8935.

[46] D. C. Cronemeyer, Phys. Rev., 1959, 113, 1222-1226.

[47] H. Liu, T. A. Ma, X. Z. Li, W. Z. Li, M. Wu, X. H. Bao, Chemosphere, 2003, 50, 39-46.

[48] A. P. Singh, N. Kodan, A. Dey, S. Krishnamurthy, B. R. Mehta, Int. J. Hydrogen Energy, 2015, 40, 4311-4319.

[49] G. M. Wang, Y. C. Ling, H. Y. Wang, X. Y. Yang, C. C. Wang, J. Z. Zhang, Y. Li, Energy Environ. Sci., 2012, 5, 6180-6187.

[50] Z. K. Zheng, B. B. Huang, J. B. Lu, Z. Y. Wang, X. Y. Qin, X. Y. Zhang, Y. Dai, M. H. Whangbo, Chem. Commun., 2012, 48, 5733-5735.

[51] L. C. Wang, Y. Wang, Y. Cheng, Z. F. Liu, Q. S. Guo, M. N. Ha, Z. Zhao, J. Mater. Chem. A, 2016, 4, 5314-5322.

[52] A. Naldoni, M. Allieta, S. Santangelo, M. Marelli, F. Fabbri, S. Cappelli, C. L. Bianchi, R. Psaro, V. Dal Santo, J. Am. Chem. Soc., 2012, 134, 7600-7603.

[53] X. Y. Pan, Y. J. Xu, ACS Appl. Mater. Interfaces, 2014, 6, 1879-1886.

[54] B. Han, W. Wei, L. Chang, P. F. Cheng, Y. H. Hu, ACS Catal., 2016, 6, 494-497.

[55] B. Han, Y. H. Hu, J. Phys. Chem. C, 2015, 119, 18927-18934.

[56] N. J. Lawrence, J. R. Brewer, L. Wang, T. S. Wu, J. Wells-Kingsbury, M. M. Ihrig, G. H. Wang, Y. L. Soo, W. N. Mei, C. L. Cheung, Nano Lett., 2011, 11, 2666-2671.

[57] D. Jiang, W. Z. Wang, E. P. Gao, S. M. Sun, L. Zhang, Chem. Commun., 2014, 50, 2005-2007.

[58] J. J. Wang, J. Y. Feng, L. Zhang, Z. S. Li, Z. G. Zou, Phys. Chem. Chem. Phys., 2014, 16, 15375-15380.
[59] A. Dabirian, R. van de Krol, Appl. Phys. Lett., 2013, 102, 033905/1-033905/4.

[60] J. L. Chen, Z. H. Hong, Y. L. Chen, B. Z. Lin, B. F. Gao, Mater. Lett., 2015, 145, 129-132.

[61] S. J. Li, X. Chen, S. Z. Hu, Q. Li, J. Bai, F. Wang, RSC Adv., 2016, 6, 45931-45937.

[62] H. Q. Ma, Z. Y. Shi, S. Li, N. Liu, Appl. Surf. Sci., 2016, 379, 309-315.

[63] G. Liu, L. Z. Wang, H. G. Yang, H. M. Cheng, G. Q. Lu. J. Mater. Chem., 2010, 20, 831-843.

[64] H. Shi, M. H. Du, Phys. Rev. B, 2014, 90, 174103/1-174103/6.

[65] T. Bak, M. K. Nowotny, L. R. Sheppard, J. Nowotny, J. Phys. Chem. C, 2008, 112, 13248-13257.

[66] J. Nowotny, T. Bak, M. K. Nowotny, L. R. Sheppard, J. Phys. Chem. B, 2006, 110, 18492-18495.

[67] C. H. Sun, T. Liao, G. Q. Lu, S. C. Smith, J. Phys. Chem. C, 2012, 116, 2477-2482.

[68] M. K. Nowotny, T. Bak, J. Nowotny, J. Phys. Chem. B, 2006, 110, 16302-16308.

[69] M. Radecka, M. Rekas, J. Am. Ceram. Soc., 2002, 85, 346-354.

[70] M. K. Nowotny, T. Bak, J. Nowotny, C. C. Sorrell, Phys. Stat. Sol. (B), 2005, 242, R88-R90.

[71] J. A. Wang, R. Limas-Ballesteros, T. Lopez, A. Moreno, R. Gomez, O. Novaro, X. Bokhimi, J. Phys. Chem. B, 2001, 105, 9692-9698.

[72] J. Y. Cao, Y. J. Zhang, L. Q. Liu, J. H. Ye, Chem. Commun., 2013, 49, 3440-3442.

[73] I. E. Grey, N. C. Wilson, J. Solid. State. Chem., 2007, 180, 670-678.

[74] L. Pan, S. B. Wang, W. B. Mi, J. J. Song, J. J. Zou, L. Wang, X. W. Zhang, Nano Energy, 2014, 9, 71-79.

[75] R. A. He, S. W. Cao, P. Zhou, J. G. Yu, Chin. J. Catal., 2014, 35, 989-1007.

[76] Y. Y. Zhu, Q. Ling, Y. F. Liu, H. Wang, Y. F. Zhu, Appl. Catal. B, 2016, 187, 204-211.

[77] J. Xu, Y. R. Teng, F. Teng, Sci. Rep., 2016, 6, 32457.

[78] C. J. Zhang, A. Michaelides, D. A. King, S. J. Jenkins, Phys. Rev. B, 2009, 79, 075433/1-075433/11.

\title{
用于太阳光催化反应的空位工程
}

\author{
${\text { 龙明策 }{ }^{\mathrm{a}, \mathrm{b},{ }^{*}} \text {, 郑龙辉 }}^{\mathrm{a}}$ \\ a上海交通大学环境科学与工程学院, 上海200240 \\ ${ }^{\mathrm{b}}$ 上海交通大学, 薄膜与微细技术教育部重点实验室, 上海 200240
}

摘要: 空位是一种点缺陷, 广泛存在于非化学计量比的半导体光催化材料的晶格中. 不同于其它研制复杂结构和组成的新 型光催化剂的策略, 空位工程设计方法可以基于传统的, 由丰量元素组成的光催化剂进行表面或体相晶格的空位调控, 以 获得宽谱响应的高效光催化材料. 该方法具有不引入杂质元素、成本低廉、方法简便等优点, 且通过表面化学吸附作用可 以耦合热催化和光催化过程, 以实现增强的选择性光催化反应.

空位的表征技术包括元素分析, 扫描隧道显微镜, 催化发光, 光致发光或顺磁共振等直接和间接观测技术. 近期正电子 湮没谱发展成为一种研究空位的重要手段. 这种方法可以区分不同位置(如体相和表面)和不同形式(如单一空位或联合空 位)的空位并确定其相对浓度, 从而用于探索空位影响光催化活性的规律.

氧、氮、硫和卤素原子空位均属于阴离子空位. 氢化处理法可以在光催化剂晶格中形成高浓度氧空位, 并导致纳米材 料表面层的晶格混乱. 处理后光催化剂的光学吸收拓展到近红外区, 电子给体浓度大大提高, 促进了电子输运和界面电荷 的迁移与分离; 然而, 可见光区的吸收对增强的光催化活性没有贡献. 氧空位还可以作为活性位点吸附和解离反应物, 促 进电子从催化剂到吸附质间的转移, 甚至直接参与到光催化和光化学反应中. 富含氧空位的 $\mathrm{WO}_{3}$ 可以耦合热催化和光催 化反应促进 $\mathrm{CO}_{2}$ 的选择性还原, 或者利用近红外光活化分子氧并选择性氧化胺. 氮空位是含氮的 $\mathrm{n}$ 型半导体光催化材料的 本质属性. 石墨氮化碳中的氮空位有助于促进电荷分离, 同时可以作为化学吸附位用于选择性吸附, 活化和还原氮气, 因 
此富含氮空位的光催化剂在还原含氮化合物方面具有应用潜力. 由于卤素原子在层状卤氧化铋的层间以较弱的范德华力 存在,该类化合物容易形成卤原子空位. 通过热处理碘氧化铋可以获得活性增强的含碘空位化合物. 空位的出现导致带隙 变宽和价带下移, 光生空穴氧化能力提高, 从而获得更好的光催化活性.

传统的n型半导体光催化剂中难以形成阳离子空位. 理论研究表明, 含阳离子空位的 $\mathrm{TiO}_{2}$ 具有一系列优点, 包括电子传 输性能提高, 载流子复合受到抑制等. 并且钠空位可以作为表面活性位促进水的吸附和离解, 从而提高光解水效率. 含钛 空位的p型 $\mathrm{TiO}_{2}$ 可以通过焙烧甘油化的前驱体制备, 钛空位的出现使得光解水和催化降解有机物活性均大幅提高. 含碳空 位的石墨氮化碳不仅表现出增强的光催化活性, 同时能够提高氧吸附并促进两电子还原氧气产生 $\mathrm{H}_{2} \mathrm{O}_{2}$ 的反应过程. 铋空 位能够有效提高铋基光催化剂 $\mathrm{BiPO}_{4}$ 和 $\mathrm{Bi}_{6} \mathrm{~S}_{2} \mathrm{O}_{15}$ 的活性. 二维纳米材料的晶面和厚度可以影响表面空位的组成和浓度. $\mathrm{BiOCl}$ 纳米片的表面是以铋空位为主, 而超薄的BiOCl纳米片则是以铋氧联合空位为主, 从而表现更优异的光催化活性.

最近研究者在含空位的高性能光催化剂制备以及性能调控规律方面取得了长足进展, 今后还将继续发展先进的表征 技术, 进一步研究空位的调控和稳定化手段, 并全面理解空位对光催化反应的影响基本规律. 空位工程将在半导体光催化 技术中发挥更加重要的作用.

关键词: 氧空位; 氢化处理; 光催化; 化学吸附; 钛空位

收稿日期: 2016-10-29. 接受日期: 2016-11-18. 出版日期: 2017-04-05.

*通讯联系人. 电话: (021)54747354; 传真: (021)54740825; 电子信箱: long_mc@sjtu.edu.cn

基金来源：国家自然科学基金(21377084); 农业部公益性行业专项(201503107).

本文的英文电子版由Elsevier出版社在ScienceDirect上出版(http://www.sciencedirect.com/science/journal/18722067).

\section{《催化学报》为被国际期刊退稿的高质量论文开辟绿色通道}

我们注意到, 国内一些高质量、原创性的研究工作在投稿到国际期刊上时, 经常因语言和写作问题等非科 学因素而被退稿和拖延发表, 甚至会失去原创知识产权, 这个损失是巨大的, 也是非常可惜的!

众所周知, 按国际学术界的共识, 获得论文的首发权并保证拥有研究工作的原创性不在于论文发表在哪个 刊物(只要是国际ISSN挂号的), 而在于谁第一时间抢先发表了工作.

为了保护作者工作的原创性和首发知识产权, 《催化学报》编委会为具有一定原创性的论文提供快速发表 的绿色通道. 对于投到国际著名期刊(如Science, Nature, Energy \& Environmental Science, Journal of the American Chemical Society, Angewandte Chemie International Edition, ACS Catalysis和Journal of Catalysis等)上催化论 文的退稿, 如果其创新性较强, 学术质量较高, 仅仅是因为语言和文章写作原因而被退稿, 《催化学报》会安排 其在最近一期上抢时间发表; 如果文章原创性较好, 不存在学风问题, 但有一些理论观点的争议、实验现象暂 时无法得到完美的理论解释, 或者需要进一步补充相关实验数据等, 本刊主编、副主编也会协助作者尽快修改 和发表相关工作.

对于国际著名相关期刊的退稿, 作者需将相应的审稿意见及意见答复等材料一并提交到本刊, 以加快论文 的处理速度. 